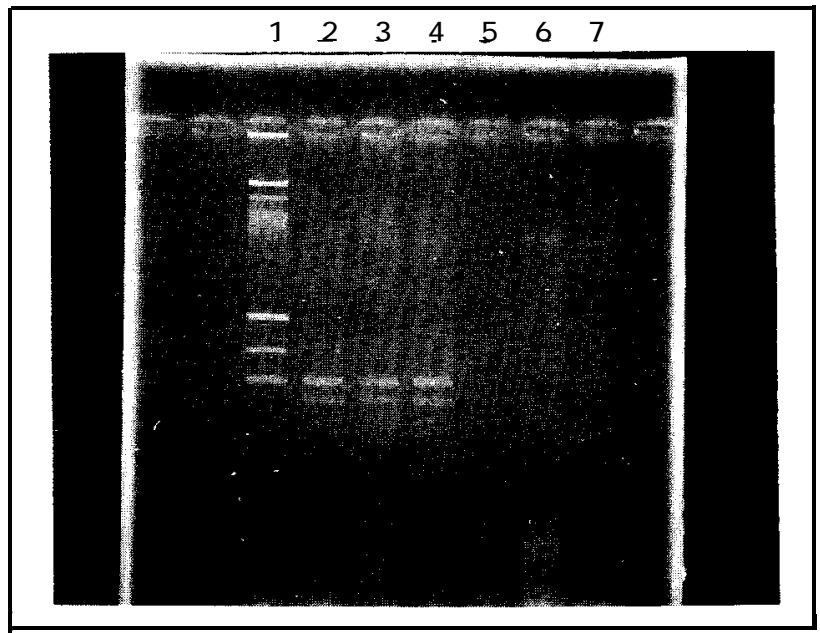

FIGURE. Plasmid profile of strains isolated from patients $A$ and $B$. Line 1, marker strain; lines 2 to 4, patient A; lines 5 to 7, patient B.

patients in our ICU. The isolates of $\mathbf{S}$ marcescens obtained from both patients had a similar biochemical profile (API20E) and antibiotic susceptibility (MICs: $\leqslant 0.5 \mathrm{mg} / \mathrm{L}$ for gentamicin and ciprofloxacin, $\leqslant 1 \mathrm{mg} / \mathrm{L}$ for imipenem, $\leqslant 2 \mathrm{mg} / \mathrm{L}$ for ceftazidime and amikacin, $\leqslant 8 \mathrm{mg} / \mathrm{L}$ for piperacillin and ticarcillin/clavulanic acid, and $>64 \mathrm{mg} / \mathrm{L}$ for amoxicillin and amoxicillin/clavulanic acid). Based on the chronological patterns of colonization, with isolates with similar antibiograms and biochemical profiles, cross-acquisition with $S$ marcescens from patient B to patient A during the first hours of admission was suggested strongly. To determine the similarity of isolates from the two patients, 17 isolates of $S$ marcescens obtained from patient $\mathrm{A}$ and 53 isolates obtained from patient B were analyzed. The strains from patient A were isolated from the oropharynx $(\mathrm{N}=3)$, rectal swabs $(\mathrm{N}=2)$, the nose $(\mathrm{N}=3)$, tracheal aspirates $(\mathrm{N}=3)$, the groin $(\mathrm{N}=3)$, and the stomach $(\mathrm{N}=3)$. From patient $\mathrm{B}$, isolates were cultured from the oropharynx $(\mathrm{N}=27)$, the stomach $(\mathrm{N}=24)$, and tracheal aspirates $(\mathrm{N}=1)$, in a time period extending 5 days before the admission of patient $\mathrm{A}$ until the day patient A succumbed. Serotyping was performed by means of a passive hemagglutination test as described by Guinée et al. ${ }^{6}$ Interestingly, all isolates from patient A had an identical serotype (010AC:Hnm), and all isolates from patient B also had an identical, but different, serotype (04,6B:H12). In addition, plasmid analysis was performed as described previously. ${ }^{7}$ In line with the results of serotyping, two different plasmid patterns were observed for the strains from patient A and patient B (Figure), thus refuting the initial suggestion of cross-acquisition from patient $\mathrm{B}$ to patient $\mathrm{A}$.

\section{DISCUSSION}

In summary, the evaluation of sequential colonization with $S$ marcescens, having similar antibiograms and biochemical profiles, in two patients treated within the same ICU and in the same period of time, strongly suggested crossacquisition leading to fatal infection for one patient. However, serotyping and plasmid analysis of multiple isolates obtained from several body sites and on several days demonstrated two patient-specific strains of $S$ marcescens. As a matter of fact, cross-acquisition probably had not occurred.

Although in some studies, similarity of bacterial isolates from the same species has been established by comparison of biochemical profiles and antibiograms, ${ }^{8}$ the potential insufficiency of that approach is demonstrated here. These data underscore the importance of genotypic and phenotypic characterization of strains for hospital epidemiological studies. However, for a practical approach, we recommend surveillance and phenotypic characterization on an ongoing basis in high-risk areas, with the addition of genotypic analysis only when outbreaks are suspected.

94-CC-133. A ddress reprint requests to M arc J.M. Bonten, $P h D$, Department of Internal M edicine, U niversity Hospital M aastricht, PO. Box 5800, 6202 AZ M aastricht, The N etherlands.

\section{REFER E N CES}

1. Torres A, Aznar R, Gatell JM, et al. Incidence, risk, and prognosis factors of nosocomial pneumonia in mechanically ventilated patients. Am Rev Respir Dis 1990:142:523-528.

2. Johanson WG, Pierce AK, Sanford JP, Thomas GD. Nosocomial respiratory infections with gram-negative bacilli: the significance of colonization of the respiratory tract. Am Intern Med 1972;77:701-706.

3. Heyland D, Mandell LA. Gastric colonization by gram-negative bacilli and nosocomial pneumonia in the intensive care unit patient. Evidence for causation. Chest 1992;101:187-193.

4. Wenzel RP Thompson RL. Landry SM. et al. Hospital-acquired infections in intensive care unit patients: an overview with emphasis on epidemics. Infect Control 1983;4:371-375.

5. Doebbeling BN, Stanley GI Sheetz CT et al. Comparative efficacy of alternative hand-washing agents in reducing nosocomial infections in intensive care units. N Engl J Med 1992;327:88-93.

6. Guinee PAM, Jansen WM. Maas HME Serotyping of Serratia marcescens using passive hemagglutination. Zentral Bakteriol und Hyg 1987;A264:105119 .

7. Sambrook J, Fritsch EF, Maniatis T. Molecular Cloning A Laboratory Manual. 2nd ed. Cold Spring Harbor, NY: Cold Spring Harbor Laboratory; 1989.

8. Bonten MJM, Gaillard CA, Johanson WG, et al. Colonization in patients receiving and not-receiving topical antimicrobial prophylaxis. Am J Respir Crit Care Med 1994;150:1332-1340.

\title{
CDC Offers 24-Hour Fax-Back of HIV Documents
}

The CDC offers a free 24-hour fax-back service of key HIV-related documents, including fact sheets and surveillance report tables. To access the National AIDS Clearing- house FAX service (NAC FAX), call (800) 458-5231, and select option 5 from the voice menu prompt. A list of currently available documents also may be obtained. 